\title{
The Role of Parents to Educate Their Children in the Midst of Technology Advancement
}

\author{
Heny Perbowosari ${ }^{1}$, I Ketut Sudarsana ${ }^{2}$ \\ \{henyperbowosar@gmail.com ${ }^{1}$,iketutsudarsana@ihdn.ac.id ${ }^{2}$ \} \\ ${ }^{1,2}$ Institut Hindu Dharma Negeri Denpasar, Bali, Indonesia
}

\begin{abstract}
Technological advancement affects human lives especially children. Therefore, parents play a very important role in educating their children to use technology in their daily lives. This study aims to describe the role of parents in providing education to children in the use of technology. This study applies descriptive qualitative method, where the data is collected through observations, interviews and documentations, which then analyzed qualitatively. The finding shows that: 1) technology advancement has positive and negative impacts on children, 2) internet use has both positive and negative impacts on children's development, 3) parents could address the technological advancement for children by doing supervision and direct the use of good and right technology.Based on the findings, it can be inferred that parents should have enough knowledge on the advantages and disadvantages of technology, ability to educate children in using technology, and ability to manage the use of technology for children, so that, the use of technology becomes something that is effectively positive for children's development.
\end{abstract}

Keywords: the role of parents, education, technology advancement

\section{INTRODUCTION}

Global development with its information and communication technology advancements that grows rapidly demands that human resources should improve through any means. One way to improve the human resources is the learning process. The learning process itself can be carried out through three institutions, namely: formal, informal, and non-formal institutions. The role of these three institutions is very important in advancing the educational process carried out in Indonesia.

Education is a conscious effort made by humans to help themselves in living their lives, so that they can continue to experience physical and spiritual growth and development, besides for themselves humans need education in order to be able to place themselves as social beings in the community, so that education can make humans alive and make a balance between individual needs and their social needs[1].

Today's education demands that all peoplecouldcope with the advancement of information and communication technology thatdeveloprapidly worldwide. Besides, they are also required to grow together with the development of the world, as well as to get knowledge and skill that can be used to compete in the work field. One type of excellent means of communication that 
vastly develop is internet. Internet is a communication media that contains data and information needed for humans, because in the internet the information from all over the world about everything is served freely and easily accessed by the people everywhere and every time. The development of the era is increasingly sophisticated and even small children in this global era are familiar with the internet.

The role of parents is very important in the education process in a family. Parents in today's era, namely in the era of globalization, have their respective jobs to support life in the family. It is not uncommon that the role of the mother, as the most important teacher for children, is replaced by the nanny. The education job from parents cannot be neglected because children start to learn not at school, but they will firstly learn in their family. So that, the parents need to understand that the children need to be educated and guided by them start from they were born until lasts, because of long-life learning. If the children do not get education, love and guidance from parents, it will give negative impacts for them and influence their education at school and in society.

When parents do not want to be disturbed while working, or when they want their childrento be silent and calm,they give their children gadgets so that their children would play at home and do not go anywhere and parents can finish their job and routines without the disruption from their children. Parents who are busy with their work usually trust their caregivers to look after and care for their children when they are not at home. Unconsciously, they will lose some important thing of their children growth and they will lose more time for them to have good quality in communication to their children to deliver some advices, morals, and values related about life and for their attitude and future education[2].

Loose attention given by parents for their children will lead to the misuse of internet. Children would access adult content without any attention.However, the internet does not always contain negative things, the internet is also very helpful for humans to access global information faster and easier. Therefore, the focus of this study is the parents'role in educating their children in the midst of technology advancement. Parents are expected to take the time to instill a good attitude, character, and also provide a good example, so that, the younger generation of world is not getting off to negative things.

\section{METHOD}

This study applies qualitative approach which gives more emphasis on the analysis than the process of deductive and inductive inference as well as on the analysis of the dynamics of the relationship between the observed phenomena using scientific logic. The data collection techniques used include; (a) observation, (b) interview, and (c) documentation. The data analysis is done qualitatively, which is carried out directly and continuously until done, through the following stages; (a) data reduction, (b) data presentation, and (c) data verification.

\section{RESULT AND DISCUSSION}

\subsection{The Role of Internet in the Development of Children}

The internet is a worldwide communication medium. The internet contains data, text, images, videos, and sounds that are displayed through computer networks. The internet is one of the information windows that helps everyone to know and to search for information that is useful for a scientific field. Besides, internet is also helped people to get information about the simple information and life hacks that can they use for their daily life. The world of education 
is in dire need of the internet in the learning process[3]. The rapid development of internet technology has spread to all corners of the world [4].

The internet has several characteristics that are very useful and helpful in realizing educational goals. Internet can be very useful and it has many applications that are suitable for its use. The characteristics of the internet according to [5] include:

a. Broad Internet Network

The internet is one of the media that comes from media tools that have functions to process and store data information. The internet is connected with telephone lines and modems.

b. Interactive Internet Media Communication

Internet interactive communication media is a medium that is used in excess of electrochemical media such as television and radio, because the internet offers a vast network over television and radio which is limited to one program.

c. Internet Information Center

The sophistication of the internet offered as a center of information because through the facility of querying and boosting using keywords users can search for the desired information so that the information obtained is unlimited and very helpful. It is also easy to access.

d. Internet Cost

With the sophistication that is owned and offered by the internet for its users, in accessing it it costs not a little. Users who are usually very dependent on the internet often provide a monthly budget for internet use that they use.

The internet in the era of globalization helps people to get information and communication quickly and easily so that almost everyone in the world uses the internet. The networking of internet has been touched every area in all over the world. By the development of the internet that is always upgraded time by time to increase the quality of it to be faster and better. One of the advantages of using the internet is to facilitate human's work in their life.It can make people's life easier, happier, more useful and more meaningful. Besides, internet also can increase income, connectionand achievement for workers who rely on the internet access.

\subsection{The Effect of Using Internet on Children}

The use of the internet has an impact on its users. The ease of technology will make users have different opinions in accepting technological advances. Technologies such as the internet aims to help the children to access a great deal of information. In the internet, there are various kinds of games that can be useful for educating children such as; introducing basic principles in teamwork, sharing skills, etc.[6]. The internet not only has a number of advantages but there are also some disadvantages. Internet may provide a lot of information for learning, but not all of them can be taken and needed by children, besides the internet also provides some links that are not suitable for children.

The positive effects of using the internet include: a) internet will provide information related to knowledge, b) expand the network of friendships online, c) facilitate communication, and d) train children's creativity. While the negative effects of the excessive use of gadgets for children are including; reducingreal life social interaction and also weakening children's emotional development[7]

Technological advances may provide an instant satisfaction for the children with the knowledge they gainand assume that everything obtained from the internet is a complete knowledge, thus making them to think less broadly and deeply. In addition, the Internet also provides many conveniences, so that future generations will be a generation that cannot stand 
to face difficulties, and assume that life is an easy matter and try to simplify problems. Thus, the child becomes resistant to all challenges and difficulties and reduces the level of patience and concentration[8]. Moreover, the internet might be used without any time control. Many children use the internet in a long period of time and intensively. It will cause a degradation in the children's relationships and communication with others, because upon the time children chat with the people in the internet, they are enjoying their solitude more. If this has happened to children, parents should be able control it, so that children can use the internet properly which can be beneficial for themselves and their life.

\subsection{The Role of Parents Against Children in Responding to the Advancement of Science and Technology}

Parents play a very important role in providing education for their children. Parents may enroll their children to formal and informalinstitutions to get a proper education [9]. However, parents still take bigger portion in giving education for their children compared with any education institutions. Although some parents' roles and functions for educating their children can be partially left to others, parents are still the first and foremost person who responsible for children's education. Many experts correlate family education and parenting/caring patternas the form of children education at home[10].

The pattern of care for children greatly determines the personality and attitude of a child. In a family, longing for children who have a noble attitude, are intelligent in knowledge, physically and mentally healthy, and can always provide happiness to both their parents and the community, so they already think not only about themselves, but also for other people [11].

The role of both parents, especially a mother who has a very important role as a first teacher and foremost for a child, because a very large mother gives love from the womb until her child is born into the world and a mother teaches things first his whole life to talk, eat, drink, and behave. When children have started to grow and develop, of course the role of the father cannot be ignored. The father has responsibility and provides protection to the family and becomes a role model in the future [12].

In this respect, the role of parents is quite important in relation to addressing the current progress, especially in the digital era, where children are consequently following any advancements in technology. Therefore, parents need to be aware of this, so that technological advances would have a positive effect on children's development. Children's development cannot be separated from the role of the family in providing stimulation to the child in order to achieve optimal maturity [13]. Along with the development of technology today, the role of parents should be able to provide selective stimulation to children should, for example the provision of gadgets to children must be adapted to the development and needs of children.

Parents also may give gadgets to children for the child to play but limit the use of the gadgets and provide understanding from an early age to make the children not to access inappropriate information consumed for children at an early age because if this is happened this will not have a good impact on the child and on the environment and future life later [14]. After it is already understood by the children, then everything will be good.

Therefore, parents should instill positive values and norms and nurture the children with faith. Parents should be selective in providing technology products to children so that children will understand the importance of using technology well. Besides, parents should conduct guidance and supervision for children in using technology especially the use of gadgets[15]. The form of guidance and supervision are;(a) accompanying the child while using the gadget, (b) supervising the child while using the gadget, and (b) making a deal about theallowed time 
in using the gadget. Parents should always interact, communicate, and take care of their children well, so that children have awareness about the negative impact on the use of gadgets and also avoid gadgetsaddiction. Besides, parents must have the consideration about the advantages and disadvantages of the technology that will be introduced to children, so that,they will not become the slave to technology, but the technology itself may provide a good effect as a tool that makes their life easier.This is in line with the results of a study by Tesa[14]who states that one of the efforts that can be made by parents in this digital era is to provide assistance, supervision and direct children to use technology thoughtfully. The appropriate use of gadgets will give positive valuesfor the growth of children themselves [16].

In addition to the above efforts, parents can also minimize the negative impact of using gadgets by: (a) providing gadgets according to the age and needs of children, (b) limiting the use of gadgets for children, and (c) avoiding addiction to gadgets. Therefore, parents must act decisively and not indulge their children to continue using gadgets. So that, there is no dependence on gadgets. If you want to give gadgets to children, you need to supervise the use of gadgets both for their children and their selves. Therefore, parents will be able to educate their children to be more independent in facing the technology advancement to get a brighter future.

\section{CONCLUSION}

The internet is an excellent communication medium used by all people in the world. Apart from the sophistication offered by internet facilities, it can also have a negative effect on its users. Therefore, parents in a family need to think of a good and appropriate school for their children so that children can learn according to their ability to receive knowledge and utilize the facilities provided in school. And in the future, children who get good knowledge are expected not only to become knowledgeable, but also have good attitudes and skills, so that,they can make the best use of technology in the era of technology advancement. The role of parents in addressing this technological advancement is by supervising and giving guidance for the children about the advantages and also disadvantagesin using gadgets so that children will not be addicted to gadgets. In addition, parents should always make quality communication with their children about the use of gadgets.

\section{REFERENCES}

[1] Kementerian Pendidikan dan Kebudayaan. Undang-undang sistem pendidikan nasional. 2003.

[2] Hulukati, W. Peran Lingkungan Keluarga terhadap Perkembangan Anak J. Musawa7 265-82. 2015.

[3] Haris, Budiman. Peran Teknologi Informasi Dan Komunikasi Dalam Pendidikan AlTadzkiyyah J. Pendidik. Islam 8 75-83. 2017.

[4] Wati, E R. Ragam Media Pembelajaran (Jakarta: Kata Pena). 2016.

[5] Effendi, M. Peranan Internet Sebagai Media Komunikasi J. Dakwah dan Komun.4. 2014.

[6] Yudiningrum, F R. Efek Teknologi Komunikasi ELektronik Bagi Tumbuh Kembang Anak UNS Digit. Libr. 2010

[7] Chusna, P A . Pengaruh Media Gadget Pada Perkembangan Karakter Anak Din. Penelit. Media Komun. Sos. keagamaan17 315-30. 2017

[8] Nanang, S. Pentingnya Peran Orang Tua Dalam Penggunaan Gadget Pada Anak Usia 
Dini J. Smart PAUD 2. 2019.

[9] Sudarsana, I K. Pemikiran Tokoh Pendidikan Dalam Buku Lifelong Learning: Policies, Practices, And Programs (Perspektif Peningkatan Mutu Pendidikan di Indonesia) J. Penjaminan Mutu2 44. 2016.

[10] Perbowosari, H. Parenting Models In Building The Religious Characters Of Children Vidyottama Sanatana Int. J. Hindu Sci. Relig. Stud.2 39. 2018.

[11] Mas, A A G R. Menjadi Orang Tua Mulia Dan Berguna (Surabaya: Paramita). 2008

[12] Titib, I M . Menumbuhkembangkan Pendidikan Budhi Pekerti Pada Anak (Perspektif Agama Hindu) (Denpasar: PT. Offset BP). 2006.

[13] Vitrianingsih, Sitti K. I C. Hubungan Peran Orang Tua Dan Durasi Penggunaan Gadget Dengan Perkembangan Anak Pra Sekolah Di Tk Gugus Ix Kecamatan Depok Sleman Yogyakarta J. Formil (Forum Ilmiah) KesMas Respati3 101-9. 2018.

[14] Alia T. Pendampingan Orang Tua pada Anak Usia Dini dalam Penggunaan Teknologi Digital A J. Lang. Lit. Cult. Educ.14 65-78. 2018.

[15] Sunita I e Mayasari E. Pengawasan Orangtua Terhadap Dampak Penggunaan Gadget Pada Anak J. Endur.3 510. 2018

[16] K. Saddhono and M. Rohmadi, "A Sociolinguistics Study on the Use of the Javanese Language in the Learning Process in Primary Schools in Surakarta, Central Java, Indonesia." Int. Edu. Stu., vol. 7 no.6 pp 25-30, 2014 